\title{
Erratum to: Computational studies on the structures and energies of the tautomers of 1-amino-3-nitrotriazol-5-one-2-oxide
}

\author{
P. Ravi - Surya P. Tewari
}

Published online: 13 October 2013

(C) Springer Science+Business Media New York 2013

Erratum to: Struct Chem (2013) 24:1347-1367

DOI 10.1007/s11224-012-0166-0

Due to an oversight the name of Ram Ramaswamy was included in the author list of the original publication. The correct author list is P. Ravi, Surya P. Tewari. It has been corrected and the affiliation is also corrected accordingly.

The online version of the original article can be found under doi:10.1007/s11224-012-0166-0. 